\title{
Spotkanie w pół drogi. O Marii Konopnickiej i Zofii Nałkowskiej (z Katherine Mansfield w tle)
}

Marię Konopnicką i Zofię Nałkowską wydaje się mniej łączyć niż oddalać. Należą do zupełnie różnych pokoleń: daty ich urodzin dzielą 42 lata, Nałkowska mogłaby być niemalże wnuczką Konopnickiej, była 12 lat młodsza od jej najmłodszej córki. Poetka przez przyjęcie kulturowej roli wieszczki, pisarza narodowego o romantycznej proweniencji, wydaje się głęboko zakorzeniona $\mathrm{w}$ wieku XIX. Słynna diarystka kojarzona jest przede wszystkim jako autorka późnych powieści i działaczka społeczna, dla większości czytelników jest więc pisarką między - lub wręcz powojenną. Okoliczności jedynego spotkania Konopnickiej i Nałkowskiej jeszcze wyjaskrawiają tę różnicę. Jest czerwiec 1907 r., Konopnicka ma wówczas 65 lat, należy do honorowego komitetu warszawskiego Zjazdu Kobiet. To ona otwiera zjazd przemówieniem $\mathrm{w}$ wielkiej sali filharmonii i zamyka go na uroczystej wieczornicy. Nałkowska, wtedy dwudziestotrzyletnia, nie jest oficjalnie zaproszona do wzięcia udziału w obradach, praktycznie wdziera się na scenę, by zaprezentować punkt widzenia kobiet najmłodszych, bezczelnie krytyczny wobec organizatorek. Wiadomo, że Konopnicka wraz z resztą prezydium opuściła zebranie. Powody tej manifestacji pozostają niejasne. Niektórzy interpretatorzy doszukują się w niej protestu przeciw skandalicznym opiniom wygłaszanym przez młodziutką referentkę, inni twierdzą, że oburzenie Konopnickiej nie miało nic wspólnego z Nałkowską; miałoby być związane albo z insynuacjami na temat jej związku $\mathrm{z}$ obecną na Zjeździe Kobiet i aktywnie weń zaangażowaną Marią Dulębianką, albo też z rozpartyjnieniem uczestniczek - ta ostatnia wersja wydarzeń znajduje potwierdzenie w źródłach i swego czasu najbardziej mnie przekonywała ${ }^{\mathrm{T}}$.

${ }^{\text {I }}$ Piszę na ten temat w: L. Magnone, Maria Konopnicka: lustra i symptomy, Gdańsk 2011, s. 354-355. 
Jeśli ta wielokrotnie powtarzana historia może być znowu interesująca, to dopiero wówczas, gdy zadamy jej zupełnie inne pytania. Przypomnimy na przykład, że w tym gorącym czasie rewolucji obie pisarki są przecież po tej samej stronie barykady: wrażliwość społeczna Konopnickiej pozwoliła socjalistom uznać ją za swoją niemalże od chwili debiutu, z radykalnym pismem „Głos” współpracowała poetka wcześniej nawet niż ojciec Zofii, Wacław Nałkowski. W kwietniu 1906 r., kiedy autorka Ajakposzedt król na wojnę specjalnie przerywa swoje podróże i wraca do Warszawy, z satysfakcją i rozbawieniem donosi dzieciom o uprowadzeniu z Pawiaka 10 więźniów politycznych przez przebranych za żandarmów działaczy $\mathrm{PPS}^{2}$, pod przewodnictwem, dodajmy, późniejszego męża Nałkowskiej, Jana Jura-Gorzechowskiego.

Możemy także zwrócić uwagę na to, że obie wtedy, niemal w tym samym momencie, występują przeciwko karze śmierci: Konopnicka pisze wstrząsający protest $\mathrm{w}$ imieniu polskich matek, przeciw „mordowani[u] tych, których wnętrzności nasze nosiły, a karmiły piersi”, opublikowany anonimowo we wrześniu

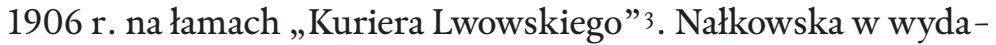
nym w 1907 r. Księciu rekonstruuje odczucia kobiety zakochanej w skazańcu, intensywnie przeżywającej ostatnią noc jego życia, do końca mającej nadzieję na ułaskawienie. Relacja z koszmarnych godzin poprzedzających powieszenie Księcia zaczyna się od zdania: „Powinni koniecznie znieść karę śmierci” “.

Zamiast konfrontować Konopnicką w wieczorze życia z młodziutką debiutantką, z pamięcią o jej losie, warto przyjrzeć się też temu, jak wyglądały późne lata Nałkowskiej. Autorki te bowiem okazują się do siebie bardzo podobne w doświadczaniu starości. Dojrzała Nałkowska, wypełniająca w PRL-u z godnością oficjalne funkcje i jednocześnie śmiertelnie nimi znużona, przypomina mi oczywiście Konopnicką, która u progu XX w. z równym wysiłkiem dźwiga insygnia „poetki narodowej”. Obie u szczytu kariery i powodzenia narzekają na obowiązki pisarskie, kolejne zamówienia odrywające je od tego, co uważają za swoją właściwą pracę. W Polsce powojennej udręczona Nałkowska, tak jak pół wieku wcześniej Konopnicka, traci czas na podpisywanie apeli, wypowiadanie się na kongresach, przygotowywanie prasowych

${ }^{2}$ List do Zofii Mickiewiczowej z 27 kwietnia 1906 r. w: M. Konopnicka, Listy do synów i córek, oprac. L. Magnone, Warszawa 2010, s. 789.

3 „Kurier Lwowski” 1906, nr 254, s. 1. Przedrukowałam ów protest w ramach publikacji: M. Konopnicka, Listy do córek $i$ synów (s. 801), omawiam go obszerniej w artykule: L. Magnone, Orzeszkowa $i$ Konopnicka przeciw karze śmierci, w: Dwie grwiazdy, dwie drogi. Konopnicka i Orzeszkowa - relacje różne, red. E. Ihnatowicz, E. Paczoska, Warszawa 2012, s. 201-218.

4 Z. Nałkowska, Ksiaże, Warszawa 1976, s. 149. 
filipik, w końcu uświetnianie własną obecnością różnych ceremonii okolicznościowych. Odczuwa podobny rodzaj klęski osobistej, bynajmniej nie niwelowanej przez uzyskaną pozycję w świecie literatury i polityki. Dopiero też niedługo przed śmiercią Nałkowska zapoznaje się z biografią poetki. Czytamy w Dzienniku pod datą 8 września 1953 r.:

[...] wstępuję do czytelni, biorę Konopnicką, jakieś zbiorowe wydanie z r. 1947 w Ameryce! Przedmowa jej przyjaciółki. Ależ życiorys! Straszny ojciec, despota i bigot, straszny mąż, despota i [luka L.M.], sześcioro dzieci, ucieczka z nimi do Warszawy i zarabianie drukowaniem wierszy na ich życie. W wierszach patos, namiętność, talent. Zachwyt światem5.

Kilka dni później dodaje: „Jest urocza. Czułość, polność, prawdziwość. No i sądy" ${ }^{6}$.

Pod koniec życia Nałkowska nieświadomie spaceruje śladami poetki: wiosną $1954 \mathrm{r}$. trafia do domu pracy twórczej w Nieborowie, skąd wybiera się na wycieczkę do Arkadii, nie wiedząc, że była to dawna siedziba rodziny Konopnickich ${ }^{7}$. Na ścieżkach parku zamilkły już dawno odgłosy przechadzek, diarystka nawet nie wie, że stąpa krok w krok za duchem poetki. Ich biografie zazębiają się, ale nie w czasie.

\section{Konopnickiej i Nałkowskiej reportaże więzienne}

Przykładem wirtualnego spotkania w przestrzeni tekstu są reportaże więzienne obu autorek, tak podobne, że aż trudno uwierzyć, iż nie były do tej pory ze sobą zestawiane. Debiut prozatorski Konopnickiej, cykl Za krata, ukazywał się na łamach redagowanego przez poetkę feministycznego pisma „Świt” w roku 1886, trzy Obrazki więzienne (Podhug ksiegi, Jeszcze jeden numer, Onufer) drukowane były w „Kraju” w latach 1887-1888. Mimo

5 Z. Nałkowska, Dzienniki 1945-1954. Część 3 (1953-1954), oprac. H. Kirchner, Warszawa 2001, s. 169.

${ }^{6}$ Ibidem, s. 186.

7 W pierwszych latach XX w. majątek pod Łowiczem wynajmowany był od księcia Michała Radziwiłła przez najmłodszego syna Konopnickiej, Jana. Arkadia odgrywa wówczas rolę familijnej przystani - tu organizowane są rodzinne zjazdy, tu też trafia pod koniec życia mąż poetki, Jarosław, po śmierci pierwszego męża zamieszkuje średnia córka Zofia, a każde wakacje spędza najmłodsza, Laura, która czyni z tego miejsca letnisko modernistycznej Warszawy (w Arkadii bywają m.in. Stanisław Przybyszewski, Stanisław Brzozowski, Tadeusz Miciński). Konopnicka wraz z Marią Dulębianką są w Arkadii rzadkimi, ale honorowymi gośćmi. 
starań autorki nigdy nie ukazały się w osobnym zbiorze; szkice Za krata zostały ostatecznie włączone do tomu Ludzie i rzeczy w 1898 r., Obrazki zaś - do wydanych rok wcześniej Nowel. Reportaże Nałkowskiej to zbiór Ściany świata (w wersji książkowej opublikowany w roku 1931), na który złożyły się opowiadania drukowane w latach 1925-1930 w czasopismach.

Chociaż zbiory te dzieli prawie półwiecze, odnaleźć w nich można wiele podobieństw, począwszy od silnej obecności pierwszoosobowego narratora, którym w obu wypadkach jest sama autorka, w celach charytatywnych odwiedzająca więzienia. W przypadku Konopnickiej nowele dokumentują jej działalność na przełomie lat 70. i 80. XIX w. Więzienia warszawskie odwiedza wówczas Konopnicka w towarzystwie Wandy Umińskiej, przez całe życie zaangażowanej $\mathrm{w}$ pomoc aresztantom i wielokrotnie zatrzymywanej w związku z nielegalną działalnością oświatową. Jej obecność jest dyskretnie sygnalizowana w pierwszym akapicie Za krata ${ }^{8}$.

Dzieło Nałkowskiej zbiera doświadczenia z czasów pobytu w Grodnie, gdzie zamieszkała po ślubie z Janem Gorzechowskim, wówczas dowódcą Żandarmerii Wojskowej, i działała jako kuratorka więzienna w latach 1924-1926. Do tej pracy pisarka namówiona została przez kontynuatorkę dzieła Umińskiej, Stefanię Sempołowską, założycielkę Patronatu (Towarzystwa Opieki nad Więźniami), tę samą, z którą blisko przyjaźniła się najmłodsza córka Konopnickiej - Laura Pytlińska, aktywna między innymi w kierowanej przez Sempołowską warszawskiej Kasie Pomocy Więźniom Politycznym. Narratorka rzadko jest w więzieniu sama, na wizyty chodzi z innymi przedstawicielami komitetu, wielokrotnie używa liczby mnogiej, w Ukojeniu na przykład w spotkaniu z Pietrowem uczestniczy „może pięć albo sześć osób” 9

Opowiadania Konopnickiej i Ściany śrwiata Nałkowskiej były, niezależnie od siebie, porównywane przez wybitne monografistki obu autorek do Zapisków z martwego domu Fiodora Dostojewskiego $^{\text {Io }}$. To zestawienie nie wydaje mi się trafne, cho-

${ }^{8}$ „U furty tego gmachu stanęłam po raz pierwszy w dzień jesienny, dżdżysty, w towarzystwie jednej z moich znajomych, która, uzyskawszy odpowiednie pozwolenie władzy, dawniej już zaczęła odwiedzać więźniów, i cieszyła się nieograniczonym ich zaufaniem". M. Konopnicka, Za krata, w: eadem, Pisma zebrane: Nowele, oprac. A. Brodzka, t. 4, Warszawa 1976, s. 58. Cytaty z nowel Konopnickiej pochodzą z wydania M. Konopnicka, Pisma zebrane: Nowele, oprac. A. Brodzka, t. 1-4, Warszawa 1974-1976. Oznaczam je dalej w nawiasie skrótem N, po którym podaję numer tomu i numer strony.

9 Z. Nałkowska, Ściany śreiata, Warszawa 1931, s. 185. Cytaty pochodzące z tego wydania oznaczam dalej w nawiasie skrótem Ś, po którym podaję numer strony.

to A. Brodzka, O nowelach Marii Konopnickiej, Warszawa 1958, s. 112 i n.; H. Kirchner, Natkowska albo życie pisane, Warszawa 2011, s. 351. 
ciażby dlatego, że powieść Dostojewskiego dokumentuje jego własne doświadczenia jako katorżnika, gdy utwory polskich pisarek opisują doświadczenia pań z komitetów dobroczynnych, po charytatywnej wizycie wracających do swoich bezpiecznych domów. Z tego względu do porównania z Dostojewskim nadawałyby się lepiej wspomnienia samej Sempołowskiej, która o swoim pobycie $\mathrm{w}$ więzieniu napisała między innymi cykl artykułów $Z$ dna nędzy, drukowanych w 1909 r. w „Prawdzie” II. Warszawska społecznica przedstawiła w nich wstrząsający obraz czwartej celi na oddziale kobiecym w areszcie policyjnym w ratuszu, do której trafiały zwłaszcza zatrzymywane na ulicy prostytutki, a także bezdomne staruszki, żebraczki, wariatki. Celę kryminalistek Sempołowska obserwuje od środka, również jako więźniarka, ale jednak w pewien sposób z zewnątrz: należy do zamkniętych w osobnej celi i traktowanych na innych zasadach, „tak zwanych «politycznych»" ${ }^{2}$, których często nieudane próby zbliżenia się do pensjonariuszek celi numer cztery dokumentuje $\mathrm{z}$ rodzajem zakłopotania i poczucia winy. Inteligentki okazują się bowiem często zbyt delikatne, czy może uprzedzone, by spełniać akty miłosierdzia, do których zdolne są kryminalistki. Sempołowska w interesujący sposób dokumentuje własną walkę z odrazą wobec zaniedbanych więźniarek, zwłaszcza starych czy chorych, wokół których koniec końców to koleżanki z celi, a nie społecznice, wykonują podstawowe zabiegi pielęgnacyjne. Dopiero podejmując starania o przeniesienie „politycznej” z celi kryminalistek, autorka zdaje sobie sprawę z dwuznaczności samego podziału na dwie cele.

Ani Konopnicka, ani Nałkowska właściwie nie zadają sobie pytania o własny dwuznaczny status, przynależą do świata spoza krat, a ich główną troską jest wybór narzędzi formalnych do zapisu więziennych obserwacji; doświadczenia charytatywne są wyzwaniem nie tylko, lub raczej nie przede wszystkim, dla ich humanitaryzmu, ale i, co niemniej istotne, dla ich sztuki pisarskiej.

Zbiory łączy też niestabilność gatunkowa. Tak teksty Konopnickiej, jak Nałkowskiej oscylują między literaturą a dziennikarstwem. Oczywiście, w czasach Konopnickiej formuła reportażu nie była jeszcze ustalona, jednak z pewnością nie jest to powód, który mógłby wyjaśnić jej wybory. Nie myślę także, że odpowiedzialny jest za nie brak doświadczenia prozatorskiego poetki. Jak przedstawiałam $w$ innym miejscu ${ }^{\mathrm{I} 3}$, na kartach reportaży

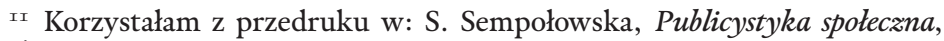
red. Ż. Kormanowa, Warszawa 1960, s. 17-49.

I2 Ibidem, s. 23.

I3 L. Magnone, Maria Konopnicka ..., s. 185 i n. 
więziennych Konopnicka ustala własną, szczególną technikę pisarską - to opis autentycznego spotkania, w któym rola narratorki ogranicza się do uważnego słuchania opowieści bohaterki. We wprowadzeniu do opowiadania Jeszcze jeden numer, będącym czymś w rodzaju zbioru rad kierowanych do osoby, która chciałaby pójść w jej ślady, Konopnicka podkreśla przede wszystkim konieczność zindywidualizowanego traktowania każdej rozmówczyni, zadzierzgnięcia „subtelnych, a tak silnych węzłów wzajemnej ufności” (Jeszcze jeden numer, N, t. 3, s. 339), które pozwolą „od płaczącej u kolan twoich lub na piersiach twoich aresztantki” usłyszeć historię jej życia, „a to w takiej rozciągłości i z takimi szczegółami, jakich żadne śledztwo dobyć by z niej nie zdołało nigdy" (Jeszcze jeden numer, N, t. 3, s. 341). Ten warsztat posłuży w latach 90 . jej nowelistyce.

Literackość utworów Nałkowskiej nie ulega wątpliwości ${ }^{14}$, grodzieńskim więzieniom autorka planowała zresztą początkowo poświęcić wielokrotnie zapowiadaną $\mathrm{w}$ wywiadach powieść ${ }^{15}$. Powstały one jednak $\mathrm{z}$ codziennych zapisków $\mathrm{w}$ dzienniku ${ }^{\mathrm{I}}$ i bywały czytane jako dokumenty ${ }^{17}$. W rozwoju literackiej kariery Nałkowskiej to również ważny etap, któremu zawdzięczamy późniejsze Medaliony, wykorzystujące charakterystyczną technikę rzeczowego sprawozdania $\mathrm{z}$ wstrząsających faktów ${ }^{\mathrm{I}}$.

Niektóre wątki obu zbiorów wprost dają się ze sobą zestawiać. Niedorozwinięta, anonimowa zabójczyni dziecka własnej siostry ze Ścian świata każe myśleć o Stanisławie Agdzie z Za krata, ślicznej obłąkanej, która zabiła swoją przybraną matkę i podpaliła dom. Historia Pietrowa z Ukojenia Nałkowskiej, który zamordował swoją gospodynię, jej syna oraz ciężko ranił kochaną przez siebie córkę, stanowi jakby wariant zbrodni tytułowego Onufra. Bohater Konopnickiej zabił swojego pracodawcę i swego podopiecznego - sierotę. Dla obu więźniów ich uczynek, wynik straszliwego afektu, oraz konieczność dalszego życia z piętnem niezrozumiałej dla nich samych zbrodni, są największą karą. Ich wewnętrzna tragedia sprawia, że różnią się od pozostałych skazanych. Pietrow „był jeszcze człowiekiem - nie więźniem” (Ś, s. 187), podobnie Onufer „zniszczony był strasz-

${ }^{1} 4$ Por. E. Kraskowska, O międzywojennej kobiecej prozie reportażowej, w: eadem, Piórem niewieścim. Z problemów prozy kobiecej dwudziestolecia międzyrwojennego, Poznań 2003, s. 174-179.

I5 Por. H. Kirchner, op.cit., s. 347-348.

I6 Por. Z. Nałkowska, Dzienniki III 1918-1929, oprac., wstęp i komentarz H. Kirchner, Warszawa 1980, s. 125-149.

${ }^{17} \mathrm{Na}$ zasadzie argumentu przytacza ich fragmenty np. Stefania Sempołowska w swojej obszernej pracy W więzieniach, red. A. Steinsberg, Warszawa 1960.

I8 Por. E. Kraskowska, op.cit., s. 177. 
nie [...]. Nie było to owo powolne charakterystyczne wyniszczenie, jakiemu podlegają dawni więźniowie i recydywiści, ale jakaś nagła i niepowstrzymana ruina, od której pomimo ogromnej budowy swojej tak zetlał, że zdawało się, iż potrącony palcem padnie o ziemię i w proch się rozsypie" (Onufer, N, t. 3, s. 347). Postać Nałkowskiej uchwycona jest w momencie, gdy jeden z członków komitetu, próbując mężczyznę pocieszyć, informuje go, że Ludmiła przeżyła: „Pietrow targnął się cały od tej wieści, nagłym małpim ruchem obie ręce przycisnął do twarzy. I w jakimś charczeniu, czy szlochu powiedział te słowa: - Ale kiedy ja już nie żyję" (Ś, s. 190). Onufry ukazany jest jako przedmiot kancelaryjnej rozmowy strażnika z recydywistą Osmólcem, na który poza narratorką nikt nie zwraca uwagi, mimo powtarzanych przezeń rozdzierających jęków: „Ani drgnął... Ani zipnął!... Jak ten ptak... Jak ten ptak... [...]. O moje dziecko, moje dziecko! O Jezu! Jezu! Jezu!” (Onufer, N, t. 3, s. 355).

Z kolei Podtug ksiegi Konopnickiej oraz historia Ołdaka przedstawiona w Zależnościach z tomu Ściany śrwiata Nałkowskiej to przypadki więźniów starających się o przedterminowe zwolnienie. Ołdaka poznaje Nałkowska, kiedy ten już od sześciu lat przebywa $\mathrm{w}$ więzieniu za niemal przypadkowe zabicie brata w wyniku sprzeczki. Ma on prawo starać się o wcześniejsze wyjście, sprawa jednak wciąż napotyka nowe trudności: „Naprzód nie chcieli z sądów odesłać papierów, później znowu było czegoś brak. Teraz czekało się na odpowiedź z gminy” (Ś, s. 82-83). Historię Ołdaka opowiada autorka na marginesie dziejów pana Opolickiego, który zostaje skazany na karę więzienia za zabójstwo żony. W zakończeniu wyjaśnia Nałkowska tytułowe „zależności”. Kiedy po dłuższej nieobecności w Grodnie narratorka powraca do wizyt w karcerze i spotyka obu mężczyzn, Ołdak tłumaczy, z jakiego powodu starania o jego zwolnienie nie przyniosły oczekiwanego rezultatu:

Gmina nic na to nie może powiedzieć. Tam mnie nie znają, bo ja w swoich stronach nigdy nie byłem, cały czas tylko po służbach - to tu, to tam. W gminie mnie nikt nie zna. [...] Więc teraz znów powiedzieli, że można przedstawić świadectwo od tych panów, gdzie służył [...]. Tak się właśnie zeszło, że oni nie żyją. Dwóch panów umarło jeszcze w wojnę, pan Ciński i pan Zawadzki. U hrabiego w Przytulicach dziesięć lat służył - też w zeszłym roku umarł. A pan Opolic$\mathrm{ki}$ - to znowu teraz sam jest tutaj w więzieniu. (Ś, s. 116)

Losy Cygana z Podług księgi Konopnickiej są równie tragiczne, przypłaca on bowiem życiem próbę ucieczki z więzienia, 
która po fakcie okazuje się niepotrzebna, jako że „podług księgi" wyrok upłynął już dwa tygodnie wcześniej i przestępca - po którym „baczniejszy spostrzegacz poznałby $\mathrm{z}$ łatwością, że [...] przebywa ten punkt krytyczny, w którym cierpienie [...] staje się na dłużej wprost nieznośnym, niemożliwym” (Onufer, N, t. 3, s. 320) - powinien zostać wypuszczony. Co szczególne, w opowiadaniu autorka nie mówi ani słowa na temat powodów, dla których Cygan znalazł się w więzieniu. Jak Nałkowska, która kończy szkic refleksją:

Ostatecznie odjechałam stamtąd znowu, nie dowiedziawszy się nigdy, jak się skończyły starania o zwolnienie Ołdaka. Nie wiem wcale, czy siedzi aż do dziś. Może to źle, że nie wykazałam w tym wypadku większego zaciekawienia, że jakby wystarczyły mi w całym tym splocie ujawnione niespodziane, daleko sięgające, chociaż tak zupełnie przypadkowe i nieważne zależności (Ś, s. 117),

tak samo Konopnicka zainteresowana jest przede wszystkim niezwykłym splotem okoliczności, indolencją administracji karceralnej, która sprowokowała więźnia do podjęcia na własną rękę próby wcześniejszego odzyskania wolności. Swoistą kontynuacją tego wątku jest u Nałkowskiej nowela Szczęście, przedstawiająca rodzaj gorzkiego happy endu: udane przedterminowe wyjście śmiertelnie chorego więźnia, który umrze miesiąc po powrocie do domu. „Jak w paru innych wypadkach - komentuje autor$\mathrm{ka}-\mathrm{i}$ tym razem uwolnienie przyszło za późno. Ale ten odjazd $\mathrm{z}$ brzydkiego, posępnego dworca, w pochmurny dzień wczesnej jesieni, do dzisiaj pozostawił $\mathrm{w}$ pamięci mojej wspomnienie szczęścia” (Ś, s. 203).

Obok podobieństw widać oczywiście znaczące różnice. W zbiorze Nałkowskiej zło i zbrodnia ukazane są przede wszystkim jako zjawiska męskie. Autorka przedstawia nam: Opolickiego, który na oczach czworga swoich dzieci zabił żonę; mordercę własnego brata, Ołdaka; wypierającego się współudziału w zabójstwie męża pani Liskiej - Rosę; uczestników napadu na Żyda - braci Kowylów i ich wspólnika Wapulę; mściwego Pietrowa. Poszukując odpowiedzi na zagadkę męskiej agresji, narratorka sięga między innymi do teorii spod znaku Cesarego Lombroso. Nałkowska uznaje, że obok ludzi, na których

zbrodnia przychodzi z zewnątrz, zwala się niespodzianie, jak zwykłe nieszczęście. Nic takiego nie ma przedtem, nic takiego nie ma potem. Chwila zbrodni wystaje z życia, sterczy osobno - obca, niezrozumiała dla nich samych (Ś, s. 82), 
istnieją również ci, na których

zbrodnia nachodzi z wewnątrz, jest wyrazem ich natury. Wyglądają tak, jakby w każdej chwili mogli ją na nowo popełnić. Ich dziwne twarze, kształt ich głowy, czasami samo tylko osadzenie oczu, sam wyraz spojrzenia mówi od razu, że są czymś innym od każdego z nas, czymś odmiennym i tajemniczym, że są zdolni do tego, co dla każdego z nas jest niepojęte. (Ś, s. 81)

Do pierwszej grupy należy Ołdak, który „zabił brata siekierą i był poza tym zupełnie dobrym człowiekiem” (Ś, s. 114). Jest on, uznaje narratorka, „niepodobny do tego, co zrobił” (Ś, s. 161), w przeciwieństwie do braci Kowylów, którzy „są tacy, że można to od razu o nich pomyśleć. Cofnięte czoło, nos płaski między oczami - to wystarcza, aby już można było być zbrodniarzem” (Ś, s. 161). Z kolei w wyglądzie Opolickiego symptomy zbrodni dostrzega narratorka post factum: „Jakże mogłam nie zauważyć tego od razu wtedy! Dopiero zbrodnia rzuciła na niego właściwe światło. Sklepienie jego brwi nad oczodołami, wąskie czoło, krótki nos, niemiła i gminna jego przystojność - to było właśnie to, właśnie to" ('́, s. 115).

Poważne traktowanie przez Nałkowską rozpoznań fizjonomistów, przywoływanie ich w latach 30. zaskakuje i niepokoi. Wydaje się szczególnie anachroniczne, gdyby pamiętać, jak często polemizowała Konopnicka z Tardem, Lombrosem i Espinasem, czy to pośrednio w swoich utworach, czy bezpośrednio w publicystyce $^{\mathrm{I} 9}$. Jest $\mathrm{w}$ tym może coś z potrzeby zachowania tego, co niepojęte, w bezpiecznym oddaleniu, zamknięciu zbrodni w kategorii inności. W kolejnych opowiadaniach tomu okazuje się jednak, że zło jest domeną nie tyle zwyrodnialców, co po prostu mężczyzn. Nieprzypadkowo chyba w Krzyku niestyszanym znajdziemy opis pięknego porucznika, spotkanego przez narratorkę w lesie podczas polowania. Choć Oniewiecki przedstawiany jest w konwencji przeestetyzowanej, to przecież nieuchronnie ten fragment przywołuje inną scenę polowania, która zamieszczona została w opowiadaniu Zależności, poprzedzającym w układzie tomu Krzyk niestyszany: odrażającą scenę dobijania postrzelonego zająca przez rozszalałego Opolickiego, przyszłego mordercę własnej żony. Jakby Nałkowska zadawała pytanie o możliwość popełnienia podobnej zbrodni także przez zakochanego $\mathrm{w}$ pani Liskiej porucznika, a także o to, co kryje się za męską rozrywką,

I9 Por. np. O thumie w: M. Konopnicka, Publicystyka literacka $i$ spoteczna, oprac. J. Baculewski, Warszawa 1968, s. 496-544. 
zabawą w zabijanie. Zresztą kiedy porucznik ukryty w samochodzie wypatruje Liskiej na ulicy, sytuacja przypomina tropienie zwierzęcia: Oniewiecki ma na sobie myśliwską, skórzaną kurtkę, czatuje nieruchomo w czarnym, nieoświetlonym wozie... Mimochodem narratorka informuje czytelnika, że małżeństwo pani Liskiej było nieudane, mąż ją „ despotyzował, podobno nawet bił" (Ś, s. 134). Przy takiej interpretacji decyzja Liskiej, by nie wiązać się z porucznikiem, zyskuje inny wymiar: kiedy kobieta mówi, że przeszkadza jej w tym wspomnienie zbrodni, odkrywa być może nie empatię i szacunek dla zmarłego w wyjątkowo brutalnych okolicznościach męża, ale strach ofiary, która zdecydowanie sprzeciwi się wpuszczeniu za próg własnego domu kolejnego potencjalnego agresora.

Takie postrzeganie męskości i agresji ma prawdopodobnie związek z sytuacją biograficzną samej Nałkowskiej, która w Grodnie przebywa jako „oficerska żona” bezwzględnego i despotycznego Jura-Gorzechowskiego, skądinąd zapalonego myśliwego. W niezwykły, choć bardzo subtelny sposób Nałkowska odsłania swe podwójne uwikłanie w opowiadaniu Złoczyńcy, w którym, jedyny raz w całym zbiorze, ukazuje się w scenerii grodzieńskiego mieszkania. Jest ono podzielone na dwie sfery: „[... przez środek domu przechodziła tam cieniutka linia, dzieląca jakby cały świat na jeden i drugi. Było to tak wyraźne, że mogłabym powiedzieć, iż zaczepiałam o nią głową $\mathrm{w}$ powietrzu, że mogłabym prawie narysować ją kredą na podłodze” (Ś, s. 166). Mieszkanie dzieli się na część „od kuchni” i „od frontu”. Pierwsza jest domeną kobiet: kucharki, służących, samej pani domu doglądającej spraw gospodarskich. To kuchennymi drzwiami wchodzą do mieszkania przybywający po prośbie, czyli przede wszystkim matki aresztantów usiłujące wybłagać pomoc dla swoich synów. Salon należy do męża narratorki, jest miejscem, w którym pełni ona funkcje reprezentacyjne i towarzyskie. Frontowymi drzwiami wchodzą rozliczni goście oficjalni, „ludzi[e] o wielkich nazwiskach i niezapomnianych czynach" (Ś, s. 167). Reprezentują oni instytucje odpowiedzialne za los tych, którzy zawłaszczają przestrzeń kuchenną swoimi cierpieniami.

I to i tamto było prawdą, niewątpliwie - choć tak różne, choć tak nie do pogodzenia [...]. Kiedyś myślałam, jakie to jest dziwne, że przez każde miejsce na ziemi przechodzi południk, który ją dzieli na dwie połowy. Teraz równie dziwnym wydawało mi się to rozłamujące rzeczywistość, głębokie pęknięcie, śmiertelna rysa - bez nadziei, bez możności, aby było inaczej. Bo na każdym miejscu ziemi i o każdej chwili jesteśmy po jednej, albo po drugiej stronie tej 
linii, która na dwoje rozłamuje świat i która przechodzi przez każdy dom. (Ś, s. 168-169)

Linia ta „na dwoje rozłamuje” również samą narratorkę, która jest jednocześnie ofiarą agresji i dominacji, przebranej w kostium „wiernej, nieubłaganej i okrutnej miłości” ${ }^{20}$, ale przecież wobec Gotowej czy Wapuliny przynależy ona do męskiej sfery władzy i wpływów. Stawia ją to w pozycji bardziej dwuznacznej niż pozostałe kobiety pojawiające się na łamach opowiadań, są one bowiem w Ścianach świata przede wszystkim ofiarami.

Kobietom zbrodniarkom zdecydowała się Nałkowska poświęcić tylko jeden zbiorowy portret, ostatni szkic tomu - Kobiety tam, tłumacząc, że proporcje tekstowe odzwierciedlają rozkład płci wśród aresztantów: w grodzieńskim więzieniu kobiet było niewiele, „śmiesznie mało” (Ś, s. 207). Jest on najbliższy więziennym opowiadaniom Konopnickiej, zwłaszcza cyklowi $Z a$ krata, w całości poświęconemu życiu warszawskich więźniarek.

Oba utwory mają wiele punktów wspólnych, przede wszystkim odwiedzające napotykają w kobiecych więzieniach podobne typy aresztantek: pomniejsze przestępczynie, skazane za kradzieże czy bójki, dzieciobójczynie, niesłusznie oskarżone. Obie autorki zatrzymują się na dłuższą chwilę przy postaciach opanowanych swoistą manią samobójczą. U Nałkowskiej jest to Łowska, zamknięta w osobnej celi i strzeżona, gdyż

cokolwiek dostała do rąk, co mogło jej do tego posłużyć, natychmiast z tego korzystała. Wiadomo było, że łyka kawałki szkła, szpilki, małe gwoździe [...]. Raz już robili jej operację i powyjmowali to wszystko z żołądka. Ale potem zaczęła na nowo. Dozorca mówił, że jak ona się rusza, albo jak ją nieść, to nawet to w niej grzechocze. (Ś, s. 224)

\section{U Konopnickiej}

sławna Zabor, [...] której nabrzmiała i trędowata twarz była ohydną maską zeszpeconą przez zażywanie arszeniku [...], z którego spożywania zrobiła sobie rodzaj sportu, że kiedy była bliską śmierci, skutkiem tych nadużyć właśnie, i oddała osobie zaufanej resztę swoich zapasów, lekarz ocenił, iż wystarczyłoby jeszcze tego dobrego na

${ }^{20}$ Z. Nałkowska, Dzienniki III 1918-1929, s. 112. Według Hanny Kirchner zasadniczym powodem zaangażowania się Nałkowskiej w pomoc więźniom mogło być pragnienie przeciwstawienia się mężowi żandarmowi - zob. H. Kirchner, op.cit., s. 225-226. 
otrucie trzydziestu ludzi. Topiąca się - i wyratowana, powieszona i odcięta - snuła się tam, jak widmo złowróżbne, nienawidzona przez wszystkich. (Za krata, N, t. 4, s. 93-94)

Zasadnicza różnica leży jednak w spojrzeniu, jakie każda z pisarek kieruje na kobiecy karcer. Podczas gdy Nałkowska sprawę wydaje się bagatelizować, kiedy stwierdza, że „kobiety w zestawieniu z mężczyznami robiły tam jak gdyby gorsze wrażenie", były mniej sympatyczne, a ,ich sprawy były małe, nie budziły grozy, ani większego współczucia” (Ś, s. 208), dla Konopnickiej to więzienia kobiece są najbardziej interesujące, jako szczególny „czarny ląd czarnego kontynentu”. Wie, że sięga, jak sama przyznaje w liście do potencjalnego wydawcy, do „materii całkiem nowej” ${ }^{21}$. Jej strategia przypomina tę, którą będzie wykorzystywała w latach 30. Wanda Melcer, podobnie szukająca sfer podwójnego czy potrójnego wykluczenia ${ }^{22}$.

Konopnicka już w pierwszych akapitach swojego reportażu przyznaje, że miejsce wygląda lepiej, niż się spodziewała, jest pozytywnie zaskoczona warunkami życia przestępczyń:

Więzienia przywykliśmy uważać jako coś bardzo ponurego i ciemnego: nie zdziwiłabym się też wcale, gdyby ściany były odrapane i brudne, okienka małe i nie dające światła, a barłóg ze słomy i dzban wody dopełniał tego urządzenia. Jasność więc kamer, ich czystość, ich obszar uderza czymś nieoczekiwanym. (Za krata, N, t. 4, s. 59)

Nałkowska wielokrotnie podkreśla, że więzienie kobiece, usytuowane w najstarszej części poklasztornych zabudowań, to najgorsze miejsce w obrębie całego zespołu karceralnego:

[...] straszna była tam grubość murów, a okna wąskie, niedające światła, zduszone pobliżem jakichś ślepych ścian. Zawsze było w tym gmachu zimno, mokro i ciemno, nawet lato nie przynosiło zmiany i ulgi. Dreszcz przenikał, gdy się tam weszło z upału, w lekkiej sukni. (Ś, s. 148)

${ }^{21}$ List z dnia 30 listopada 1889 r. do Stanisława Tomkowicza, redaktora „Czasu” (M. Konopnicka, Korespondencja, oprac. K. Górski, t. 1, Wrocław 1971, s. 122). Por. artykuły Stanisława Milewskiego poświęcone prekursorstwu szkiców więziennych Konopnickiej opublikowane na łamach „Gazety Penitencjarnej” (1980, nr 17-22) oraz „Prawa i Życia” (1985, nr 41).

${ }^{22}$ Por. W. Melcer, Czarny lą - Warszawa, Warszawa 1936, a także: eadem, Po tamtej stronie życia oraz Nocuje w przytulku, w: Polskie drogi: wybór reportaży z lat międzywojennych, oprac. J. Dąbrowski, Warszawa 1962. 
[...] straszne było gineceum tej instytucji. Szpital i oddział dla kobiet to były najgorsze miejsca. (Ś, s. 208)

Nałkowskiej przeszkadza na kobiecym oddziale brak rygoru i porządku, który znamionował oddziały męskie. W jej oczach więźniarki „nie miały naprawdę tej godności, co mężczyźni, nie miały żadnej dumy, nie było w nich nawyku ani spokoju, nie wiedziały, że trzeba panować nad sobą" (Ś, s. 210). Zamiast stać się więźniami, szczególnym ludzkim typem opisywanym wielokrotnie na łamach zbioru przez autorkę ${ }^{23}$, kobiety - szczególnie te, którym towarzyszą urodzone już w karcerze niemowlęta, „bezradne i oszalałe” - przemieniają się w „stado zbolałych samic, ciasno zamkniętych i jednego tylko pragnących, w swej nędzy pragnących rzeczy wzniosłej: ratować, chronić, pielęgnować, zębami i paznokciami bronić tych żałosnych, małych ludzi" (Ś, s. 212).

Konopnicka dokonuje podobnych obserwacji - kiedy w Podług księgi opisuje przemiany, jakim podlegają więźniowie w miarę upływu kolejnych lat wyroku, jak zmienia się ich postawa, cera i wyraz oczu, aż po jakimś czasie „wszyscy się upodabniają. Człowiek przestaje istnieć jako indywiduum, a zamienia się w cząstkę tej szarej, bezbarwnej, niekształtnej masy, która się nazywa ludnością więzienną" (Podtug księgi, N, t. 3, s. 318). Zauważa jednak: ,[...] rzecz dziwna, przeobrażeniu temu podlegają głównie mężczyźni. Kobiety wszystkie prawie zachowują nienaruszoną odrębność swoją przez długie lata i dopiero najstarsze, po wielokrotnych powrotach dogasające tu aresztantki ulegają niwelującym wpływom więziennego życia" (Podtug ksiegi, N, t. 3, s. 318). Konopnicka, odwrotnie niż Nałkowska, z podziwem odnotowuje opór stawiany przez aresztantki unifikacyjnym zabiegom systemu penitencjarnego, w tym na przykład ich starania o zachowanie własnego ubioru $\mathrm{w}$ miejsce więziennego drelichu, przywiązanie do miłostek i pogaduszek, pozwalających na pokrycie nieprzyjaznej przestrzeni siecią zwykłych, znanych $\mathrm{z}$ wiejskich gromad zachowań.

W Za krata autorka porównuje pod tym względem „Serbię” (areszt śledczy na Pawiaku) i więzienie na Złotej. W zdecydowanie gorszym świetle przedstawia to ostatnie:

Tam był świat cały sam w sobie, dziwny, oryginalny, zaciekawiający w najwyższym stopniu; tu dom karny, biuro, zamknięcie na ludzi

${ }_{23}$ „We wszystkich nich było to samo, związane $\mathrm{z}$ ich stanem niewoli: bladość, powolność spojrzenia, obojętność. [...] Im dłużej siedział, tym więcej było w nim więźnia, a mniej człowieka” (Ś, s. 185-186). 
i rzeczy. Tam praktykował się cały system indywidualnego sprytu z jednej strony a różnorodnej pobłażliwości z drugiej; tu karność wykonywa się chłodna, jednostajna, poważna, raz na zawsze do wszystkich jednakowo zastosowana. (Za krata, N, t. 4, s. 81-82)

„Serbia”, choć również była przestrzenią więzienną, przez respektowanie kobiecej odmienności pozwalała zachować podmiotowość. Prawo „męskie”, prawo „więziennego drelichu zacierającego wszelkie różnice" (Za krata, N, t. 4, s. 85), wtrąca kobietę w szaleństwo. „Karność, praktykowana przy ulicy Złotej, dwojako oddziaływa na uwięzione - pisze Konopnicka. Jedne $\mathrm{z}$ nich zapadają niemal $\mathrm{w}$ apatię, graniczącą $\mathrm{z}$ idiotyzmem, drugie podlegają zwodniczemu podnieceniu nerwów" (Za kratą, N, t. 4, s. 88).

Nałkowska nigdy nie zbliża się do żadnej z uwięzionych kobiet. Chociaż $z$ ukaranymi więźniami rozmowy podejmuje, aresztantki zdaje się omijać $\mathrm{z}$ daleka, nie zadaje im pytań, nawet gdy cisną jej się na usta, tak jak w przypadku niedorozwiniętej młodej dziewczyny, która zabiła dziecko swojej siostry, a w więzieniu zajmuje się własnym ${ }^{24}$. Jedyne doświadczenie zmysłowej bliskości z kobietami z tamtej strony muru to próbowanie więziennej zupy, opisywane zresztą z niesłychanym emocjonalnym chłodem:

Jak zwykle i wszędzie w takich okolicznościach kosztowało się tej zupy z miseczki. Brało się łyżkę zupy do ust i połykało z wysiłkiem, z niewątpliwym obrzydzeniem - ale zarazem z poczuciem, że tak wypada, że to jest dlaczegoś dobrze. Pamiętam, że smak miała jednak możliwy do zniesienia. Rozumiało się przynajmniej, co to jest - i nawet pływał w tym świeży koperek. (Ś, s. 214-215)

Poczucie obrzydzenia przy smakowaniu więziennego obiadu wydaje się symbolem uczuć, jakie w ogóle wzbudza w Nałkowskiej więzienne gineceum. Uczucie wstrętu nie jest obce Konopnickiej, która także dokumentuje trud przełamania instynktownej odrazy. Czyni to jednak w zdecydowanie innym stylu niż zaciskająca zęby na łyżce Nałkowska. Najlepiej wysiłek empatii autorki Za kratą oddaje opis spotkania z dzieciobójczynią Szymczakową. Tak pisze o niej Konopnicka:

${ }^{24}$ „Nikt nie zapytał, dlaczego. To było zbyt okropne i zadziwiające. Bo rzecz niewiarygodna - każdy jednak tego oczekiwał, każdy byłby wolał, gdyby zabiła swoje... Jak gdyby to miało być naturalniejsze” (Ś, s. 213). 
Była to ohydna baba. Tęga, barczysta, dość słuszna, twarz miała ospowatą jakby, z której dawna czerwoność przeszła w jakiś żółto- ceglasty, brudny odcień; kości twarzy tej były nadmiernie wystające, szczęki ogromne. Pod niskim, zachmurzonym czołem oczy małe, ponure, czasem jakby martwe, to znów latające, niespokojne, przestraszone jakieś. Była to jedyna $\mathrm{z}$ aresztantek, która przez ten rok cały nie przemówiła do mnie ani słowa. (Za krata, N, t. 4, s. $69-70$ )

Narratorka przyznaje, iż sama również nie szuka zbliżenia z Szymczakową: „[...] powiem nawet, że czułam do niej jakiś wstręt, jakąś odrazę" (Za krata, N, t. 4, s. 70). Jednak pewnego dnia, gdy Konopnicka czyta zgromadzonym w izbie więziennej Zachreycenie Lenartowicza,

kiedy przyszło miejsce o tych niechrzczonych dzieciątkach, które się po otchłaniach tułają, nie mogąc zaznać spokoju, ruszyła się ku ogólnemu zdziwieniu Szymczakowa spod pieca i ciężkim krokiem, jakby ją kto po niewoli ciągnął, przyszła usiąść tuż przy moich nogach. Padła raczej niż usiadła i wielką swoją głowę, związaną w czerwoną chustkę, położyła mi na kolanach. Muszę wyznać, że wzdrygnęłam się mimo woli. Głos mi się targnął, gorąco uderzyło do twarzy. Przemogłam się przecież i, nie przerywając czytania, położyłam rękę na tej wielkiej, ciężkiej głowie. Wkrótce uczułam, jak się ten kolos oparty o mnie, zaczął spazmatycznie wstrząsać; a kiedy po kwadransie jakimś czytanie się skończyło, podniosła się Szymczakowa ciężko, stęknęła tak, jakby wielki ciężar dźwigała, i powlokła się pod piec na zwykłe miejsce swoje. A ja wtedy zobaczyłam, że mam suknię od łez jej mokrą. (Za krata, N, t. 4, s. 71)

Najdramatyczniejsze jest jednak zetknięcie narratorki z „Dziką", mieszkanką tytułowej celi w obrazku Jeszcze jeden numer. Piękna dziewczyna, przywieziona dla zabawy przez rosyjskiego oficera jako łup z tureckiej wojny i wkrótce porzucona, została zamknięta $\mathrm{w}$ więzieniu $\mathrm{z}$ powodu braku dokumentów. Osadzono ją w osobnej celi, jako że w wieloosobowej izbie „tak jej się zara coś w głowie zaczęło psuć":

[...] ino ciągle chodziła, rękami wymachiwała i cości gadała a gadała, ale po jakiemu, to nikt nie mógł wiedzieć [...]. To znów jak na nią przypadło, to się cięgiem śmiała. „Cha, cha, cha! Cha, cha, cha!” Aż się, bywało, tak zmorduje, że się o ziemię jak drewno ciśnie i targa się za włosy i płacze tak, że aż się człowiekowi coś dzieje słuchając. (Jeszcze jeden numer, N, t. 3, s. 343) 
Gdy narratorka wchodzi do jej „numeru”, dziewczyna leży na tapczanie twarzą do ściany, głęboko wciśnięta w poduszkę. Na spojrzenie i gniewne, szorstkie słowa strażnika odpowiada w nieznanym języku ze złością i wzgardą. Jednak dostrzegłszy narratorkę, „powolnym, jakby zawstydzonym ruchem odgarnęła z twarzy włosy, spuściła nogi, poprawiła suknię i podniosła się nie zdejmując ze mnie coraz głębszym cieniem zachodzących oczu" (Jeszcze jeden numer, N, t. 3, s. 344). Zanim odwiedzająca więzienie kobieta zdąży cokolwiek powiedzieć, Dzika wpada w swój zwykły szał, zaczyna drżeć, uderzać głową w ścianę, zanosić się na przemian spazmatycznym płaczem i niepowstrzymanym śmiechem. Atak trwa ponad kwadrans. Narratorka, choć jest przerażona, nie ucieka, histeryczny napad słabnie. Wówczas - jak wspomina Konopnicka -

rozpięłam jej stanik i zmaczawszy chustkę w dzbanku położyłam ją na drgającym sercu biednej dziewczyny. Siadłam potem przy niej, objęłam ją i przycisnęłam głowę jej do piersi. Po śmiechu przyszło łkanie, rozdzierające zrazu i rozpaczliwe, potem coraz cichsze, coraz cichsze, aż się rozpłynęło w westchnienia. Zmrok zapadł już zupełnie, kiedy Dzika głęboko zasnęła.

Wtedy jej głowę złożyłam na poduszce, otuliłam ją kołdrą i wyszłam cicho na palcach. (Jeszcze jeden numer, N, t. 3, s. 345)

Jedyne autentyczne spotkanie, do którego dochodzi w opowiadaniu Kobiety tam, i którego historia zamyka Ściany świata, to zetknięcie Nałkowskiej z "zamkniętą, tajemniczą, nigdy niezrozumiałą Łowską" (Ś, s. 209). Po raz pierwszy narratorka mija się ze zbrodniarką w pociągu, $\mathrm{z}$ daleka: jest pasażerką pierwszej klasy, podczas gdy Łowską transportują z więzienia na kolejny proces. To z powodu aresztowanej pociąg staje na chwilę na węzłowej stacji, co zakłóca spokojną podróż. Kiedy po przerwie koniecznej na umieszczenie niemogącej poruszać się o własnych siłach morderczyni w wagonie pociąg rusza, przedział staje się ,na nowo cichym, ciepłym, jasnym wnętrzem, chroboczącym łagodnie i kołyszącym do snu. Ale drzemiąc myślałam, że tamta jedzie także, że - pomimo wszystko - jedzie razem" (Ś, s. 226). Narratorka doświadcza poczucia obcości względem kobiety do tego stopnia, że podróżowanie $\mathrm{z}$ nią jednym pociągiem wydaje się niemożliwe, jakby było zaburzeniem ustalonego porządku: Łowska zdaje się przynależeć raczej do tego, co na zewnątrz („,ciemność, chłód i deszcz”), nie zaś do przytulnej przestrzeni cywilizacji i postępu.

Rok po tym zdarzeniu narratorka asystuje przy procesie Łowskiej mającej odpowiadać za przerażające zbrodnie, do których 
nakłoniła kochanka, w tym za zabicie jej męża i siostrzenicy. W opisie przewodu sądowego nie znajdziemy poczucia wspólnoty i wiary w niewinność, jaka cechowała relacje Ireny Krzywickiej $\mathrm{z}$ sądu nad Gorgonową ${ }^{25}$, jednak jest coś szczególnego w sposobie, w jaki charakteryzuje Nałkowska tę „małą, prowincjonalną lwicę, przywykłą do cudzego posłuchu" (Ś, s. 230). Opis Łowskiej niemal sprawia wrażenie groteskowego wyolbrzymienia, jakby parodii stylu bycia samej Nałkowskiej, jej karykaturalnego odbicia w krzywym zwierciadle:

Zeznawała cicho i spokojnie, siedząc, jak dama, naprzeciwko sędziów, którzy patrzyli na nią z drugiej strony stołu. W otoczeniu obcych ludzi, pośród tych wszystkich mężczyzn - wrogów, prześladowców, tropicieli - była jeszcze raz kobietą, przywykłą chcieć i rządzić, przywykłą układać cudze życie i decydować o cudzej śmierci wedle zachceń swej jedynej, tajemniczej woli. Mówiąc, przykładała chusteczkę do ust, a potem opuszczała rękę wzdłuż biodra. I strzęp futra przy rękawie i ta chusteczka, i gest ręki - to wszystko stwarzało jeszcze jakiś pozór, było żałosną aluzją do wykwintu, ostatnim śladem ozdoby życia. (Ś, s. 232-233)

Ostatecznie Łowska zostaje skazana na śmierć przez powieszenie - suchą relacją, cytatem ze sprawozdania sądowego, kończy się zarówno opowiadanie, jak i cały zbiór. To nagłe, urwane zakończenie zaskakuje czytelnika, wytrąca $\mathrm{z}$ równowagi. Nie mniej dziwaczne jest otwarcie zbioru. Jak podaje Hanna Kirchner, układ opowiadań w tomie nie odzwierciedla kolejności ich powstawania ${ }^{26}$. O ile jednak Kobiety tam rzeczywiście zostały opublikowane jako tekst ostatni, kilka lat po pozostałych, już po wyjeździe autorki z Grodna, Rodzinę Marcji pisała Nałkowska jednocześnie z Zależnościami czy Złoczyńcami, długo po Szczęściu, Krzyku i Ukojeniu, i dopiero ex post postanowiła umieścić ją na pierwszym miejscu wydania książkowego, chociaż poza jednym niewielkim epizodem utwór nie nawiązuje do tematyki więziennej i sprawia raczej wrażenie - trafnie określiła to Kirchner - czegoś w rodzaju „suplementu do Domu nad tąa$m i{ }^{27}$, który ukazał się w roku 1925 . Z pewnością jego zadaniem jest ustawienie całości w odpowiedniej perspektywie czasowej -

25 I. Krzywicka, Niepokojacy wyrok, w: eadem, Kontrola wspótczesności. Wybór międzywojennej publicystyki społecznej i literackiej z lat 1924-1939, red. A. Zawiszewska, Warszawa 2008, s. 106-134.

${ }^{26}$ H. Kirchner, op.cit., s. 347.

${ }_{27}$ Ibidem, s. 356. Z kolei Kraskowska uznaje tę nowelę za „wyraźną prefigurację Niecierpliwych” - zob. E. Kraskowska, op.cit., s. 176. 
historie grodzieńskie opowiadane są bowiem nie na bieżąco, jak w relacji Konopnickiej, nie w reportażowej bezpośredniości, lecz z oddalenia, również przestrzennego. Strukturą Ścian śzerita rządzi mechanizm pamięci, podobnie jak Domem nad łąkami, kończącym się wyznaniem: „Tęskniłam za moim domem. A oto jestem tu znów i jeszcze raz" ${ }^{28}$. Dla narratorki okres pobytu w Grodnie jest już zamknięty. Wspomina go, będąc ponownie „u siebie”, w wołomińskich Górkach: „Oto jeszcze jeden z moich powrotów. Wracałam już bowiem tyle razy. A każdy powrót jest inny" (Ś, s. 190). To oddalenie będzie wielokrotnie podkreślane w całym zbiorze, w wygłosach niemal wszystkich opowiadań, szczególnie zaś w Krzyku niestyszanym, którego pierwsze zdania brzmią:

Powróciłam tutaj, do mego domu nad łąkami - jak dawniej, jak zawsze - by jeszcze raz wyleczyć się z tych ran, które zadała mi moja niedola, i z tych, które zadało mi moje szczęście [...]. Powróciłam jak zawsze - aby tu zmóc się i przezwyciężyć jeszcze raz, aby wielkie zło i wielkie dobro mego życia rozważyć, pojąć i przyjąć. (Ś, s. 121)

W zakończeniu przypomina Nałkowska: „I teraz jestem daleko stamtąd, jestem tutaj [...]. Jestem tutaj, ale myślę jeszcze o tamtym, co minęło" (Ś, s. 157).

Nowela Rodzina Marcji i cały więzienny zbiór zaczyna się od refleksji nad tym, jak pozornie niewiele przez 20 lat zmieniło się w okolicy ukochanego domu nad łąkami. Na przykładzie rytuału wypasania koni Nałkowska rozważa o przemijaniu i tożsamości: „Chłopcy są tacy sami, ale nie ma między nimi ani jednego, któryby był ten sam”; „,konie są takie same i wszystko robią tak samo. Ale i pomiędzy niemi nie ma ani jednego $\mathrm{z}$ tamtych czasów [...]. Te same są tylko ich obrzędy, ta sama jest łąka i las. I ja tutaj w oknie jestem ta sama" (Ś, s. 9, 13). W aktualnym czasie noweli opowiedziany jest tylko ten jeden letni wieczór, podczas którego odwiedza autorkę ciotka Marcji, stara Michałowa. To spotkanie przywołuje wspomnienia związane z Marcją, nieślubną córką siostry Michałowej, przez całe życie tęskniącą za nieznanym ojcem i utraconym bratem, wspomnienia, które powoli, kapryśnie, na zasadzie kolejnych skojarzeń odsłaniane są przed czytelnikiem. Meandryczna narracja ma oddać stopniowe zdobywanie przez samą narratorkę wiedzy o historii tej rodziny, aż po kończące nowelę wyznanie domykające wątek Marcji, która okazuje się w rzeczywistości córką Michała, męża swojej ciotki.

${ }_{28}$ Z. Nałkowska, Dom nad tąami, Warszawa 1978, s. 126. 
Klamrę opowiadania stanowi nie tylko powiedzonko Michałowej: „Już jak się komu nie sykuje, to się już nie sykuje”, ale i motyw powracających do stajen wypoczętych, napasionych koni. Chociaż wszystko się zmieniło - Marcja nie żyje, przez okolicę przetoczyła się wielka historia (I wojna światowa, odzyskanie niepodległości) - wszystko wygląda „jak kiedyś, jak zawsze” (Ś, s. 74).

Według Kirchner zbiór Ściany świata otwarty został Rodzina Marcji, gdyż Nałkowskiej chodziło o uniwersalizm, ,zakorzenienie zła w całej rzeczywistości i w każdym człowieku" ${ }^{29}$. Ani ten, ani inny dopuszczany przez monografistkę powód takiej decyzji, czyli oddalenie możliwych skojarzeń ze sprawą brzeską, aktualną w momencie publikacji książki $3^{\circ}$, nie wydają się wystarczająco wyjaśniać tego zaskakującego zabiegu. Nie uzurpując sobie rozwikłania zagadki, chciałabym jedynie zauważyć, że wysunięcie tej noweli na początek więziennego tomu skutkuje znaczącą feminizacją jego tematyki, a także zamyka go w swoistej kobiecej klamrze. Rodzina Marcji jest opowieścią o niewinnej ofierze, prześlicznej, chorej służącej oddanej wbrew własnej woli i wbrew złożonej jej przez Nałkowską obietnicy do zakładu dla obłąkanych ${ }^{3}$, zaś Kobiety tam kończą Ściany śweiata historią wyrachowanej zbrodniarki, kobiety potwora.

Zabieg kompozycyjny Nałkowskiej komplikuje jej pozycję jako bohaterki Ścian świata. Większa część nowel dokumentuje przejmującą empatię, chwilami niemal utożsamienie się autorki z więźniami, oparte na wejściu przez nią samą w rolę ofiary. Jak więźniowie, tak sama Nałkowska są względem reprezentantów władzy w sytuacji absolutnego podporządkowania. $\mathrm{W}$ relacji z pokrzywdzonymi przez grodzieńską administrację stłamszona oficerska żona odnajduje szczególny rodzaj pokrzepienia, notowała wszak w dzienniku z niemal przesadną czułością: „Wrócę do nich i będę wracała. Tyle im zawdzięczam. Pełną głowę mam myśli o nich $\mathrm{i}$ - jeżeli tak można powiedzieć - pełne serce miłości. Jakże ich kocham, jakże gorąco i niecierpliwie pragnę choć najbardziej malutkiej ich radości, jakiegoś cienia ulgi” ${ }^{2}$. Jednak wobec Marcji to ona jest krzywdzicielką, zaś we wstrętnej postaci Łowskiej zobaczy przejaskrawioną własną twarz, i przerazi się tym brutalnym odbiciem. Opatrując grodzieńskie wspomnienia taką klamrą, Nałkowska niejako dystansuje się od siebie z okre-

${ }^{29}$ H. Kirchner, op.cit., s. 356.

$3^{\circ}$ Ibidem, s. 348 .

${ }^{\text {I }}$ Zdarzenie to miało miejsce wiele lat wcześniej, pisze o nim Nałkowska w dzienniku, w notatce z 8 lipca 1917 r. - zob. Z. Nałkowska, Dzienniki 1909-1917, oprac. H. Kirchner, Warszawa 1976, s. 451.

${ }^{2}$ Z. Nałkowska, Dzienniki III 1918-1929, s. 128-129. 
su małżeństwa z Gorzechowskim, poddaje swoje wspomnienia sprawdzianowi czasu. Kilkakrotnie w tomie można przyjrzeć się walce między egotyzmem a wysiłkiem empatii, na przykład w otwarciu Krzyku niestyszanego, w którym rozważania wokół własnych cierpień i niepewności ucina Nałkowska, jakby przywołując się do porządku: „,...] ale nie o tym wcale chcę mówić. Mam przecież opowiedzieć tę cudzą sprawę, koło której przeszłam, nie umiejąc ani pomóc, ani zapobiec, ani naprawić” (Ś, s. 122).

Można chyba zaryzykować stwierdzenie, że na kartach Ścian śziata dochodzi do jakiegoś zasadniczego przesilenia na gruncie pisarstwa Nałkowskiej, która pokonuje drogę odwrotną do tej przemierzonej wcześniej przez Konopnicką. Dla autorki Za krata wychylona ku innemu, dokumentarna forma reportażu była bowiem punktem wyjścia, ukoronowaniem eksperymentów z prozą natomiast stał się 20 lat później na wskroś intymny, modernistyczny cykl opowiadań Na normandzkim brzegu. Nałkowska stopniowo rezygnuje nie tylko z egocentryzmu cechującego jej modernistyczne powieści, ale także z charakterystycznej dla jej okresu młodopolskiego nadorganizacji językowo-stylistycznej, zmierzając w kierunku czystej, precyzyjnej narracji Medalionów, wobec których Ściany śzeriata stanowią rodzaj prefiguracji33. $\mathrm{W}$ połowie drogi te tak różne autorki przecież się spotykają.

\section{Konopnicka, Nałkowska, Mansfield}

W Redzinie Marcji zawarta jest autonomiczna nowelka, opis wizyty, jaką narratorka w czasie wyjątkowo chłodnych Świąt Wielkanocnych składa wujostwu Marcji, rodzinie żebraków. Podczas tych i kolejnych odwiedzin narratorka myśli głównie o pięknym mahoniowym łóżku, na którym umiera Łoński:

Szerokie łoże z kolumienkami, ze śladami po wydartych brązach, w matowej, poranionej politurze, całe rude z poniewierki i opuszczenia [...]. Oto, o czym rozmyślałam sobie, słuchając skarg Łońskiego, widząc jego cierpienie. Rozmyślałam uparcie - jak gdybym wydrzeć chciała to legowisko spod niego, oddać do odnowienia i sama widzieć, jak przez cieniutkie szkliwo subtelnej politury prześwieca żółto-czerwone słońce mahoniu. Zdaje się bowiem, że nie jest w naszej mocy nie być złymi. Możemy tylko nie chcieć, starać się nie dać temu wyrazu. Możemy co najwyżej nie robić źle, ale to nie jest jeszcze wszystko. (Ś, s. 39-40)

33 Por. H. Kirchner, op.cit., s. 356. 
Jej wzrok przyciąga także „mała idiotka”, starsza córka Łońskich, obłąkana, całymi dniami siedząca na podłodze i obierająca kartofle. W zakończeniu tej mininoweli narratorka przychodzi do chałupy po raz ostatni, już po śmierci staruszka. Wszyscy domownicy wyszli, znajduje się więc w towarzystwie trupa i obłąkanej: „Popatrzyła na mnie uważnie od ziemi, jak małe zwierzę, pokazała ręką z zabłoconym nożykiem na umarłego, coś zabełkotała, czego nie pojęłam - i zupełnie zwyczajnie zapłakała. Nikogo tam nie było, więc przez chwilę siedziałam z nią, nic do niej nie mówiąc" (Ś, s. 44). Ten fragment kojarzy się ze specyficzną techniką nowelistyczną Konopnickiej, której liczne utwory kończą się sceną odwiedzin narratorki u umierającego bohatera lub (częściej) bohaterki. Ze względu na powracający motyw przykuwającego spojrzenie przedmiotu - pięknego łóżka - najbardziej podobny jest chyba do zakończenia Maryśki. Ujawniająca się w nim autorka opowiada, jak odwiedziła umierającą na tyfus dziewczynę.

Kiedym do izby weszła, usłyszałam płacz dziecka i stukot biegunów kolebki. Kolebka, z paru deszczółek nędznie sklecona, ustawioną była tuż przy łóżku, na którym leżała Maryśka. Na brzeżku kolebki siedział „Jantoś” w równie brudnej, jak dawniej, tylko nieco krótszej koszulinie i odbijając się bosą piętą od ceglanej podłogi kołysał dziecko piszcząc monotonnym głosem: - Aaaaa!... Aaaaa!... W całej izbie znać było wielką biedę. (Maryśka, N, t. 2, s. 153)

Umierająca nie jest $\mathrm{w}$ stanie odpowiedzieć na pytane o samopoczucie, narratorka wysłuchać musi więc przydługiej relacji starej Jędrzejowej, rozpaczającej nad córką.

Stojąc tuż przy chorej i słuchając wzdychania Jędrzejki podniosłam oczy na ścianę - dopowiada Konopnicka. - Na ścianie, tuż nad łóżkiem, pomiędzy świętymi obrazami, tyko poniżej nieco, wisiały na gwoździu nowo podzelowane, z wyczernionymi cholewami, trochę tylko kurzem przysute - nie sprzedane Antkowe buty. (Maryśka, N, t. 2, s. 154)

Tego charakterystycznego chwytu nie zapożycza oczywiście Nałkowska bezpośrednio od Konopnickiej - już raczej od Czechowa, którego, podobnie jak Maupassanta, można uznać za mistrza autorki Maryśki. Utwory Konopnickiej nie wpisują się $\mathrm{w}$ pozytywistyczny model noweli; pisarka programowo rezygnuje z podążania za Falkentheorie, ukutą przez Heysego koncepcją noweli idealnej, która naśladować powinna słynnego 
Sokoła Boccaccia. Tak jak Czechow i Maupassant, Konopnicka unika przerostu intrygi, gwałtownego wtargnięcia pointy oraz obnażania struktury, jej utwory cechuje

całkowite podporządkowanie przebiegu linii napięcia i charakteru efektu końcowego wewnętrznej, psychologicznej motywacji, wysnuwającej się jakby samodzielnie z toku przeżyć i refleksji bohaterów, a tylko subtelnie cieniowanej odpowiednimi posunięciami obecnego lub ukrytego narratora ${ }^{34}$.

Ma też ogromną samoświadomość artystyczną: chociaż w entuzjastycznych ocenach debiutanckiego zbioru Catery nowele mówiło się o jego autorce jako o „przyszłej powieściopisarce” 35 , nigdy nie podjęła ona prób powieściowych, gdyż dobrze wiedziała, że do tego, co chce przekazać, najlepiej nadaje się właśnie forma krótkiego opowiadania. Przypomina w tym mistrzynię modernistycznej nowelistyki, Katherine Mansfield.

Nowozelandka, której twórczość uznaje się za szczytowe osiągnięcie kobiecej nowelistyki, wielokrotnie wskazywała na dzieła Czechowa jako na źródła swoich inspiracji. Tak jak u Konopnickiej, w utworach Mansfield znaleźć można podobne, otwarte zakończenia. Ich opowiadania są nastawione na psychologicznie przeżywaną chwilę, stąd bywają pozbawione klasycznej intrygi, niekonkluzywne i zapraszające czytelnika do interpretacji, której nie sugerują, nad dopowiadającego, analizującego narratora przedkładają subtelne autocharakterystyki postaci w dialogu, wyznaniu, monologu wewnętrznym, ale także $\mathrm{w}$ ich postępkach, gestach, odruchach. Clare Hanson, dokonując interesującego rozróżnienia między short story a short fiction, twierdzi wręcz, że autorka Upojenia tworzyła te drugie, jako że programowo odrzucała wszelką opowieść, historię, „the pleasing shape and coherence of the traditional short story", którą postrzegała jako zafałszowanie nieciagłłej i heterogenicznej natury doświadczenia ${ }^{36}$.

Również u polskiej nowelistki fabuła ograniczona jest do niezbędnego minimum i służy za punkt wyjścia perypetii wewnętrznych. Bliskie są twórczości Konopnickiej tak liryczny, osobisty ton Mansfield, jak wyraźny w jej utworach nacisk na

34 A. Brodzka, op.cit., s. 362.

35 W. Bogusławski, Maria Konopnicka, „Cztery nowele”[recenzja], „Gazeta Polska” 1888, nr 45, s. 2-3. Bogusławski będzie namawiał Konopnicką do napisania powieści jeszcze w 1901 r. - zob. M. Konopnicka, Listy do synów..., s. 657.

$3^{6}$ C. Hanson, Short Stories and Short Fictions, 1880-1980, London 1985, s. 55. Cyt. za: S.J. Kaplan, Katherine Mansfield and the Origins of Modernist Fiction, Ithaca-London 1991, s. 83. 
perspektywę postaci, zwłaszcza kobiet, przy bezstronności rozumiejącego, empatycznego narratora. Obie pisarki cechuje precyzja zapisu psychologicznych obserwacji, doskonała znajomość psychiki dziecka i kobiety. Zbliża je również fakt, że w dziełach Mansfield wyraźniejsze niż u innych modernistów jest opowiedzenie się po stronie słabszych, ofiar, nacisk na opresję kobiet czy - szerzej - ludzkie cierpienie. Wystarczy przywołać utwory takie jak: Garden Party, Odkrycie, Życie Mamy Parker, Panna Brilb7.

Autorka Preludium wierzyła w możliwość intuicji, w sensie bergsonowskim ${ }^{3}$ : wierzyła, że obserwator może stać się tym, co obserwuje. Swoiste zespolenie obserwatora i przedmiotu miało pomóc w uniknięciu zarówno pułapki subiektywizmu, jak i złudzeń obiektywizmu. W liście do swojej przyjaciółki, malarki Dorothy Brett, pisała, że według niej, by namalować jabłko, trzeba „changing into an apple” ${ }^{39}, \mathrm{w}$ innym miejscu dowodziła:

Without emotion writing is dead; it becomes a record instead of a revelation, for the sense of revelation comes from that emotional reaction which the artist felt and was impelled to communicate. To contemplate the object, to let it make its own impression... is not enough. There must be an initial emotion felt by the writer, and all that he sees is saturated in that emotional quality. It alone can give incidence and sequence, character and background, a close and intimate unity $4^{\circ}$.

Podobny moment czułego rozpoznania leży u źródeł nowelistyki Konopnickiej. Jak już dawniej próbowałam dowodzić, właściwa jest jej utworom figura anagnorezy - mimo różnic społecznych dzielących autorkę-narratorkę od bohaterki jedna odnajduje się w drugiej, łączy je bowiem specyficzne kobiece doświadczenie ${ }^{4}{ }^{\mathrm{I}}$. Niemal jak w Upojeniu, w którym Mansfield opisuje spotkanie Berty i Pearl: ,[...] obie jak gdyby pochwycone $\mathrm{w}$ to koło nieziemskiego światła, doskonale rozumiejące jedna drugą, istoty $\mathrm{z}$ innego świata, zapytujące siebie, co mają

37 Por. ibidem, s. 191.

${ }^{8}$, , [I]ntuicją zwiemy ten rodzaj współodczuwania, za pomocą którego przenikamy wewnątrz jakiegoś przedmiotu, aby utożsamić się z tym, co ma on w sobie jedynego, a więc niewyrażalnego". H. Bergson, Wstęp do metafizyki, w: idem, Myśl i ruch. Dusza i ciało, przeł. P. Beylin, K. Bleszyński, Warszawa 1963, s. 19.

39 S.J. Kaplan, op.cit., s. 182.

$4^{\circ}$ K. Mansfield, Novels and Novelists, New York 1930, s. 183. Cyt. za: S.J. Kaplan, op.cit., s. 182-183.

${ }^{4}$ Por. L. Magnone, op.cit., s. 215-216. 
robić z całym tym skarbem błogiego szczęścia, który płonął w ich piersiach i opadał srebrnym kwieciem z ich włosów i dłoni” ${ }^{42}$.

Przywoływana scena z Rodziny Marcji jest jednocześnie konopnicko-czechowowska i mansfieldowska, przypomina znane opowiadanie Mansfield Garden Party ${ }^{43}$ - historię hucznego przyjęcia w ogrodzie, które nie zostaje odwołane mimo wiadomości, że w biednym domku obok odbywa się czuwanie nad tragicznie zmarłym woźnicą. Jedynie młodsza córka pani domu ma wyrzuty sumienia z powodu beztroski ucztujacych ${ }^{44}$, dlatego po udanej zabawie wymyka się, by zanieść żałobnikom koszyk resztek z pańskiego stołu. Mansfield mistrzowsko opisuje niestosowność odczuwaną przez wystrojoną Laurę, kiedy ta staje w nędznej chałupie naprzeciw trupa, wdowy i pięciorga osieroconych dzieci, a jednocześnie jej dziwny zachwyt niecodzienną sceną. Mimo przerażenia Laura myśli, patrząc na zmarłego: „Jakie znaczenie miały dla niego garden-party i koszyki, i koronkowe suknie? Znajdował się daleko od tego wszystkiego. Wyglądał cudownie, pięknie. Gdy oni śmieli się, gdy muzyka grała, we wsi objawił się ten oto cud. Szczęśliwy jest... szczęśliwy" ${ }^{4}$. Kiedy wraca do domu, na pytanie brata: „Czy to było straszne?”, dziewczyna odpowiada, łkając: „Nie, to było po prostu cudowne. Ale Laurie - urwała; spojrzała na brata: - Czy życie nie jest... wyjąkała - czy życie nie jest?... Ale czym właściwie jest życie, tego nie umiałaby wytłumaczyć. Wszystko jedno. On i tak rozumiał doskonale. - Prawda, kochanie - potwierdził Laurie" ${ }^{46}$. Ten wymiar rewelacji, objawienia, epifanii łączy wszystkie trzy nowelistki. Tak Konopnicka, jak Nałkowska mogłyby konkurować o tytuł „polskiej Katherine Mansfield”, i to podobieństwo każdej z nich do Nowozelandki uzmysławia ich wzajemne powiązanie.

Hanna Kirchner tylko raz zestawia Nałkowską z Konopnicką, przy okazji analizy zbioru Charakteryz roku 1922. Badaczka dostrzega, że niektóre utwory - te poświęcone przedstawicielom biedoty, jak Dzieciństwo, Wiench, Janowa - kojarzyć się mogą z ,realistycznymi obrazkami obyczajowymi Orzeszkowej i Konopnickiej" ${ }^{47}$. Autorka tej obserwacji zaraz jednak dodaje, że

${ }_{42}$ K. Mansfield, Upojenie, w: eadem, Upojenie $i$ inne opowiadania, przeł. W. Peszkowa, I. Tuwim, J. Stawiński, Warszawa 1962, s. 149.

43 K. Mansfield, Garden Party, w: eadem, Garden Party, przeł. B. Kopelówna, Warszawa 1958, s. 53-73.

44 „Mamo, czy to, co robimy, nie jest właściwie strasznie bez serca?”. Ibidem, s. 65 .

45 Ibidem, s. 71.

$4^{6}$ Ibidem, s. 71-72.

47 H. Kirchner, op.cit., s. 194. 
jest to podobieństwo pozorne, „gdyż nową jakość tworzy w nich syntetyczna zwięzłość i dobór elementów służących nie tyle rodzajowej prawdzie, ile refleksji ogólnej nad fenomenem losu i świadomości postaci” ${ }^{8}$. Paradoksalnie, sądząc, że kataloguje różnice, Kirchner zwraca uwagę właśnie na te cechy opowiadań Nałkowskiej, które równie dobrze mogłyby charakteryzować nowelistykę Konopnickiej, co widać zwłaszcza, kiedy sugeruje, że u Nałkowskiej zasadniczo

odmienna jest rola narratora - medium mowy postaci (Dziecinstwo), świadomości porządkującej zapis monologu starego chłopa, Wiencha. W opowiadaniu Janowa narratorka układa najkrótsze epitafium dla tego ludzkiego stworzenia, mówi tak, jakby mówiła Janowa o swoim życiu zamkniętym w samych faktach [...]. Fakty starczają za komentarz. $\mathrm{W}$ tej postawie narratora jest skupiony, żarliwy szacunek moralny i zrozumienie zasadniczej wspólnoty losu ludzkiego ${ }^{49}$.

Przecież to właśnie u Konopnickiej po raz pierwszy na taką skalę dochodzi do próby przekazania doświadczenia niezapośredniczonego, ograniczenie roli narratora do funkcji fatycznej, służebnej wobec dominującego nurtu mowy postaci, nacisk na samocharakteryzujące się wypowiedzi bohaterów i pełną empatii uwagę, z jaką wysłuchuje się ich historii. Przytoczone zdania, którymi Kirchner opisuje Janowa Nałkowskiej, mogłyby bez żadnej zmiany odnosić się na przykład do jej Banasiowej.

Nie Charaktery wybrałabym jednak, by najwyraźniej tę bliskość obu autorek wykazać, chociaż warto zauważyć, że wśród ineditów Konopnickiej znajduje się teka zatytułowana Charaktery, zawierająca opatrzone autentycznymi nazwiskami psychologiczne szkice o tytułach brzmiących zupełnie jak z Nałkowskiej: Człowiek twardego serca, Młody dziedzic, Pan Atanazy, Ten, który czeka na swoja godzinę ${ }^{\circ}$. Właściwszy wydaje mi się tu Dom nad takami. Jego pierwotny tytuł, Dzieje sasiedzkie, wprost kojarzy się z Konopnickiej Moimi znajomymi, zbiorem nowel pisanych niemal równocześnie $\mathrm{z}$ opowiadaniami więzienny$\mathrm{mi}$, opatrzonym epigrafem z Imaginy: „O, gdyby nie wy, proste wierne dusze/ Com was znalazła, jak się skarb znajduje...”. Tom Konopnickiej jest mniej spójny niż przemyślana struktura cyklu opowiadań Nałkowskiej, uznawanego zresztą przez samą autorkę za powieść. Również i w nim dominują jednak nowele

$4^{8}$ Ibidem.

49 Ibidem, s. 194-195.

$5 \circ$ A. Brodzka, op.cit., s. 340. 
utrzymane $\mathrm{w}$ podobnym nostalgicznym tonie, przedstawiające wspomnienia pisarki z okresu dzieciństwa w Kaliszu oraz lat młodzieńczych spędzonych w Bronowie i Gusinie. Oba zbiory (a w wypadku Konopnickiej niemal całość jej nowelistyki) cechuje jawna autobiograficzność, tożsamość autorki i narratorki, co przekłada się na narrację pierwszoosobową. Nałkowska przypomina sobie dorastanie na wołomińskich Górkach, przepuszczając wspomnienia przez świadomość dostępną małej dziewczynce, którą rekonstruuje nadrzędna - dorosła - narratorka. Taki sam filtr narracyjny wykorzystany został w wielu nowelach Konopnickiej, najwyraźniej chyba w Anusi, w której pisarka stosuje podwójną perspektywę:

[...] narracja utrzymana jest $\mathrm{w}$ pierwszej osobie i bynajmniej nie ukrywa faktu retrospektywności spojrzenia osoby dorosłej na minione obserwacje i przeżycia. Film odbity jest na ekranie wrażliwości dziecięcej, lecz kontrolowany i dyskretnie komentowany z uwydatnieniem odległej perspektywy czasowej i wskazaniem granic możliwości poznawczych dziecka ${ }^{5}$.

To „ujawnianie chwytu”, które Alina Brodzka uznaje za charakterystyczną cechę nowel Konopnickiej, dobrze stosuje się również do zabiegów Nałkowskiej w Domu nad łąami, w którym, jak zauważa Kirchner, „opowiada w zasadzie osoba dorosła, z perspektywy minionego czasu, ale w tej ramie mieści się też punkt widzenia dzieci" ${ }^{52}$.

Co właściwe jest obu autorkom, to także specyfika owej autobiograficzności - sprowadzonej do kilku mniej istotnych elementów własnych życiorysów - i położenie akcentu na unieśmiertelnienie innych osób $\mathrm{z}$ najbliższego otoczenia. Zarówno Dom nad łakami, jak i nowele Konopnickiej skoncentrowane są na dramatach kobiecych. Państwo Dziobakowie kojarzą się z małżeństwem Józefowej; los Millerowej, której po śmierci męża i syna córka nie chciała przyjąć do domu, bitej i wypędzanej (aż staruszka musiała iść na żebry, gdzie zginęła bez śladu), przypomina nieszczęsną Banasiową Konopnickiej, która ściągnęła do dzieci „na umieranie”, i naraża je na konieczność wykupywania „karty-pobyt”. Jej stoicyzm, oczekiwanie na śmierć 53 zadziwiają narratorkę i budzą w niej szacunek, tak jak ,niezapomniane sło-

$5^{\text {I }}$ Ibidem, s. 153-154.

$5^{2}$ H. Kirchner, op.cit., s. 199.

53 „A toć ja tej śmierci wyglądam, a wyglądam, co dnia, co godziny... [...]. Jak takie twarde życie we mnie je, to może jeszcze i ten rok płacić będzie trzeba...”. M. Konopnicka, Banasiowa, N, t. 2, s. 174-175. 
wa pogody i afirmacji”, owo „Mąż pójdzie do roboty, syn poleci do kolei, ja wyjdę, popatrzę i wesoło mnie" ${ }^{54}$ nędzarki Millerowej przechowywane w pamięci jako „wzór godny i zarazem trudny do naśladowania" ${ }_{55}$ przez narratorkę Domu nad tąkami. Historia dziewcząt z rodziny Kwietniów, oddających się gajowemu nie tylko za wiązkę drewna, ale siłą jakiejś trudno zrozumiałej miłości, przywodzi na myśl tytułową Krystę ze zbioru Konopnickiej, kobietę podobnie zniewoloną przez pożądanie, przedkładającą racje erosa nad wiejski konwenans, a nawet własne życie.

Do dzieła Konopnickiej podobna jest u Nałkowskiej też warstwa stylistyczna Domu nad takami, w tym „nasycenie narracji cechami języka i punktu widzenia mieszkańców tej okolicy”, wybierane „Zamiast dosłownego cytatu gwarowego" ${ }^{6}$. Z polemiki z Beldonkiem Dygasińskiego wiemy, że Konopnicka była przeciwna posługiwaniu się $\mathrm{w}$ narracji odautorskiej gwarą, a w wypowiedziach postaci dopuszczała jedynie najistotniejsze elementy strukturalne dialektu, tworząc mowę chłopską „w ogóle", podobną do języka poetyckiego folkloru 57 .

Bliskość ich techniki widać oczywiście szczególnie w zestawieniu z nowelami Konopnickiej tych opowiadań Nałkowskiej, w których występuje podobny typ bohatera z nizin społecznych, jednak wszystkie powyższe uwagi odnieść można również do jej wcześniejszych małych próz z opublikowanych przed I wojną światową tomów Koteczka, czyli białe tulipany i Lustra. Mimo że przedstawia w nich Nałkowska zupełnie inne środowiska, opisując już nie bohaterki wiejskie i robotnice, lecz przerafinowane wielkomiejskie elegantki, skupia się również na uniwersalnych problemach kobiecych i posługuje się podobną, choć mniej jeszcze wypracowaną, techniką. Pouczające jest na przykład zestawienie noweli Koteczka, czyli białe tulipany z opowiadaniem Mansfield Upojenie. Z kolei Zielone wybrzeże przypomina Córki pułkownika Mansfield, a także Pannę Florentynę Konopnickiej. Warto skądinąd zauważyć, że kiedy jedyny raz wspomina o Nałkowskiej Brodzka w swojej książce na temat nowelistyki poetki, to po to, by porównać Pannę Florentynę do... Niedobrej mitości, ze względu na tragiczny klimat walk wewnętrznych, znamienny dla nowoczesnej noweli psychologicznej $5^{8}$.

54 Z. Nałkowska, Dom nad takami, s. 9.

5 Ibidem, s. 8.

${ }^{56}$ H. Kirchner, op.cit., s. 198.

57 Pisałam o tym w mojej książce: L. Magnone, Maria Konopnicka..., s. 391 in.

$5^{8}$ A. Brodzka, op.cit., s. 248. 
W pracach poświęconych literaturze anglosaskiej Elaine Showalter poświęca sporo miejsca autorkom tworzącym w ostatniej dekadzie XIX i pierwszej XX stulecia, które wypełniają lukę między dwiema wielkimi figurami kobiecej powieści, George Eliot a Virginią Woolf59. Ich twórczość pozwala zrozumieć dynamikę przejścia od modelu prozy kobiecej dominującego w wieku XIX - począwszy od twórczości Jane Austen, przez utwory Charlotte Brontë, po dokonania autorki Mbyna nad Flossa - do eksperymentów powieściowych charakterystycznych dla okresu międzywojennego, rozpoczętych publikacją rewolucyjnych powieści: Pani Dalloway i Do latarni morskiej. Co charakterystyczne, autorki te tworzą nie powieści, tylko małe formy prozatorskie. Według badaczki na pojawienie się tego specyficznego nurtu wpływ miały głównie przemiany rynkowe związane z ewolucją praktyk wydawniczych, zwłaszcza odejściem od standardowego formatu three-decker, czyli typowej trzytomowej edycji powieści, a także rozwojem pism literackich, chętnie publikujących krótkie utwory. Kobiety zostały w ten sposób ośmielone do próbowania swych sił, co przełożyło się między innymi na obniżenie wieku debiutu (w pierwszej połowie wieku XIX autorki były w chwili publikacji pierwszego utworu trzydziestolatkami lub miały lat więcej, w drugiej połowie wieku były w większości po dwudziestce). Symboliczny wymiar musiała mieć również śmierć odgrywającej poniekąd rolę poetic mother Eliot - w roku 1880. Nie bez znaczenia był też fakt konsolidacji ruchu emancypacji kobiet i wzrost świadomości feministycznej, w tym pojawienie się typu kobiety nowoczesnej (new woman), oraz związane z nimi narastanie męskiej reakcji - mizoginicznych teorii dotyczących kobiecej organizacji duchowej, w tym oczywiście szczególna kariera „histerii” jako etykiety dla wszystkich tych niestandardowych zachowań i wychodzenia z tradycyjnej roli, nieoszczędzająca wielkich pisarek.

Większość autorek zaliczanych do tego nurtu znana jest wyłącznie z kilku utworów, czasami wręcz z jednego tekstu, czy nawet metafory, jak w przypadku The Yellow Wallpaper Charlotte Perkins Gilman oraz słynnego „egipskiego papierosa” Kate Chopin; ich dzieła znaleźć można raczej w zbiorowych antologiach niż w osobnych wydaniach tekstów jednej pisarki. Najwybitniejsza nowelistka anglosaskiego modernizmu, Katherine Mansfield, jest już przedstawicielką następnego pokolenia: oba tomy jej opowiadań ukazują się na początku lat 20. Jednak to

59 Zob. antologie Daughters of Decadence. Women writers of the Fin-de-Siècle, red. E. Showalter, London 1993 oraz E. Showalter, A literature of their own. British women Novelists from Brontë to Lessing, Princeton 1977. 
właśnie jej twórczość wydaje się ukoronowaniem tego procesu. W utworach, które wyszły spod pióra Nowozelandki, kondensują się bowiem wszystkie cechy noweli nurtu fin de siècle.

Zaadaptowane do przemian dokonujących się w tym samym czasie w literaturze krajowej rozpoznania Showalter pozwalaja zauważyć, że w polskim pisarstwie kobiecym tamtej epoki można wyznaczyć podobny rodzaj pasa transmisyjnego - rozciągnięty na kilkadziesiąt lat okres, w którym następuje przejście od modelu kobiecej powieści realistycznej Orzeszkowej i Zapolskiej do powieści międzywojennej spod znaku Marii Kuncewiczowej lub Anieli Gruszeckiej. Zaliczenie do tego grona Zofii Nałkowskiej nie sprawia większych trudności: rówieśnica Virginii Woolf i Katherine Mansfield sama posługiwała się określeniem „kobieta nowa” i bardzo świadomie włączała w artystyczne dyskusje epoki. Jednak także Konopnicka, choć dużo starsza, swoje odważne próby prozatorskie podejmuje dopiero w latach 90. XIX w., dzieląc intuicje $\mathrm{i}$ inspiracje $\mathrm{z}$ autorkami młodszego pokolenia i wpisując się w epokę kobiecej short story, rozpoczętą około 1890 r. Podobnie jak w literaturze anglosaskiej, i u nas przemiany te dokonują się w obrębie małych form: są to więc przede wszystkim właśnie nowele Marii Konopnickiej, ale także późne opowiadania Orzeszkowej ze zbiorów Iskry, Chwile i Przędze, Szkice Marii Komornickiej, niektóre próby Marii Jeanne Wielopolskiej (cykl miniatur Faunessy) oraz oczywiście modernistyczna twórczość Zofii Nałkowskiej, jej opowiadania i wczesne minipowieści. Powstałe w epoce Młodej Polski, pozostając na marginesie głównonurtowych przemian tego okresu - czyli męskich eksperymentów z powieścią oraz rozkwitu kobiecej poezji - z punktu widzenia potencjalnej feministycznej historii literatury wydają się nie do przecenienia. Gdy na twórczość Konopnickiej i Nałkowskiej spojrzy się z tej perspektywy, okazują się one zaskakująco sobie bliskie.

\section{LENA MAGNONE}

\section{A Meeting Halfway: On Maria Konopnicka and Zofia Nałkowska (with Katherine Mansfield in the Background)}

The author discusses the relationships between Maria Konopnicka's and Zofia Nałkowska's works, the two writers who are usually contrasted. The main body of the article is a comparison between Konopnicka's prison reports, written for the press in the 1880s, and the 1931 shortstory collection by Nałkowska, Ściany świata [The Walls of the World]. For Nałkowska, the author of Za krata [Behind the Bars], the documen- 
tary form of a press report was an opening point, and her experiments with prose were crowned twenty years later with the intimate, modernist short-story collection called Na normandzkim brzegu [On the Shores of Normandy]. Nałkowska goes in the opposite direction: she gradually turns away not only the from the egocentrism of her modernist novels, but also from the over-structured language and style of her Young Poland phase. She was going in the direction of the pure, precise narrative of Medaliony [The Medallions], for which Ściany świata are a kind of prefiguration. The author of the article proposes to conclude that both writers met halfway.

The convergences between short-story writing by Konopnicka and some works by Nałkowska (Charaktery, Dom nad takami) have been underscored by the comparison with Katherine Mansfield, a comparison which seems obvious for both Polish writers. Both Konopnicka and Nałkowska could be described as "the Polish Katherine Mansfield", and the similarity is the best indication of the relationship between the two writers.

Keywords: Zofia Nałkowska, Maria Konopnicka, Katherine Mansfield, short-story, press report.

Lena Magnone - doktor, absolwentka Wydziału Polonistyki oraz Instytutu Stosowanych Nauk Społecznych UW. Pracuje w Zakładzie Literatury i Kultury Drugiej Połowy XIX Wieku UW, wykłada również na podyplomowych Gender Studies w Instytucie Badań Literackich PAN. Autorka monografii Maria Konopnicka. Lustra i symptomy (2011). Wydała z rękopisów Listy do synów i córek Marii Konopnickiej (2010). Przygotowuje książkę na temat recepcji psychoanalizy w polskiej kulturze przed rokiem 1939. 